\title{
Energy use pattern analysis of rockmelon (Cucumis melo) production in Malaysia: a case study
}

\author{
${ }^{1}$ Liyana, N.A. and ${ }^{2, * P e b r i a n, ~ D . E . ~}$ \\ ${ }^{1}$ Faculty of Plantation and Agrotechnology, Universiti Teknology MARA Shah Alam, 40450, Selangor, \\ Malaysia \\ ${ }^{2}$ Faculty of Plantation and Agrotechnology, Universiti Teknologi MARA Melaka, Jasin Campus, 77300, \\ Merlimau, Melaka, Malaysia
}

\begin{abstract}
Article history:
Received: 22 July 2020

Received in revised form: 30 August 2020

Accepted: 11 December 2020

Available Online: 20

December 2020
\end{abstract}

Keywords:

Energy,

Crop production,

Rockmelon,

Sustainable farming

DOI:

https://doi.org/10.26656/fr.2017.4(S5).014

\begin{abstract}
Preservation of energy resources for crop production is a crucial act in an endeavour to make agriculture more sustainable. In response to that matter, this study aims to analyse and evaluate energy use pattern and its economic in rockmelon (Cucumis melo) production in Malaysian farms. Face-to-face interviews with the sampled farmers were employed to collect the data through a case study in Klang district, Selangor state of Malaysia. The collected data was then analysed using mathematical operations and spreadsheet software. The results indicated that the total energy inputs in rockmelon were 4475.62 MJ/ha. The highest portion, which accounted for $73.29 \%$ of the total energy inputs were consumed by fertilizers, while the lowest portion was used for seed $(0.01 \%)$. The total energy inputs were formed from $85.12 \%$ indirect energy and $14.88 \%$ direct energy; and $85 \%$ non-renewable energy and $15 \%$ renewable energy. The net energy and energy productivity values were $11332.85 \mathrm{MJ} / \mathrm{ha}$ and $2.81 \mathrm{~kg} / \mathrm{MJ}$, respectively. The farmers gained $29.94 \%$ profit margin from their farms business. The ratio of energy output -inputs in rockmelon production was 5.34. As the ratio was much greater than 1 , thus, conclusively, the energy inputs used by the farmers in the process of rockmelon production was highly efficient.
\end{abstract}

\section{Introduction}

Energy is an important input when running agriculture since the production process in agriculture depends on energy. In agriculture, energy is utilized from on-farm to off-farm, even up to the delivery of its final products. In line with its use and role, the demand for energy in agriculture is continuously increasing due to an increase in population and limited sources of arable lands. In order to remain sustainable, the importance of energy preservation has been continuously a prime interest for both user and producer of energy in agriculture. Otherwise, inefficient energy use raises environmental issues and the extinction of natural resources in both developing and developed countries.

Thus, well-management along with strong concern on energy resources in crops production are important factors in creating agriculture more sustainable in line with economic growth. This is coinciding with Midilli et al. (2006), Bórawski et al. (2019) and Jankowski et al. (2020), who have mentioned the idea that natural resources should be used effectively with a higher percentage of renewable resources in the process of satisfying consumers has become modern theories of economic growth.

In Malaysia, according to Saidur et al. (2011), the agriculture sector used about $1 \%$ of the total national energy demand. Although this sector used a small portion of the total energy, the overall energy efficiency of this sector was still low. The average overall energy efficiency of the agriculture sector in Malaysia was found only to be $22 \%$. The percentage is much lower than that of Norway. In the Malaysian agriculture sector, the energy is used for producing major crops such as palm, rubber, paddy and cocoa plantations to supply food and other end uses for society. Therefore, it can be summarized that good strategy and appropriate technology should be established for sustainable and profitable energy use in crop production in Malaysia

The rockmelon (Cucumis melo) is among the new promising fruit crops in Malaysian agriculture to meet 
the demand for local and global markets. The Department of Agriculture (DOA) Malaysia (2018) revealed the production of this crop reached 5845.81 metric tons from 313.4 ha planted areas throughout the country in 2018, which means the output of the crop gave an average yield of about 18.65 metrics ton of yield for every one hectare planted area. The output was much greater than the paddy fields in Malaysia with an average yield of approximately 4.031 metric tons per hectare in the same year (Statista, 2020). Hence, looking at its recorded crop yield, rockmelon has economic potential to be cultivated as an important fruit crop in Malaysia and can be expended into a large-scale fruit farm business.

As it has an economic potential, besides consistently producing high yield, great attention should also be given to the efficiency of the rockmelon production system though adopting efficient energy use in the crop production system. Exploration of efficient energy use in production system could give new findings that can be employed to sustain environmentally friendly rockmelon production and also enhance the economic benefits for its producers or famers.

Particular studies in efforts of exploring energy use efficiency in crop production system in Malaysia's agriculture have been revealed in research literature. Muazu et al. (2015) audited energy inputs and output for sustainable wetland paddy cultivation in Malaysia. Azwan et al. (2016) examined energy utilization in Malaysian oil palm mechanization operation. Nazri and Pebrian (2017) reported energy consumption in pineapple cultivation in Malaysia. Zulekipli and Pebrian (2019) studied energy consumption in rubber cultivation in Malaysia. Elsoragaby et al. (2019) analysed energy and greenhouse gas emissions in respect to both planting methods, transplanting and broadcast seeding methods in rice production in Malaysia. However, to the best of our knowledge, no one has studied the energy use pattern analysis of rockmelon in Malaysia. The available past studies concerning melon production were conducted by Baker et al. (2000), who emphasized economic and energy analysis of musk melon production using plasticulture. Moradi et al. (2015) investigated energy use and economic analysis of seedy watermelon production for different irrigation systems in Iran. Another study was carried out by Vescera and Brown (2016), who investigated the effects of three production systems on muskmelon yield and quality in New England. The findings of these past studies could not be applied to Malaysia's rockmelon farms. This is due to their farmland characteristics and cropping system, as well as climate variability and environment of Malaysia, which are different from countries of origin of these past studies.

This study aims to investigate and analyse the energy use pattern in the current rockmelon production process in Malaysia. Emphases are given on the energy inputoutput and energy-yield performance. Specifically, the outcome of this study would be beneficial in developing management strategy on energy use in rockmelon production as well providing the basis of the further steps for developing this crop into a large-scale fruit farm business in the country. Generally, it is also useful for enhancing databases of energy use in crops production in Malaysia.

\section{Materials and methods}

Comprehensive data collection for this study was carried out at rockmelon farms in the district of Klang, Selangor state of Malaysia, from January to February 2013. The district was known as newly planted areas of rockmelon in Selangor state. A total of 12 sampled rockmelon farmers were randomly selected as the respondents of the study. The samples represented about $66 \%$ of the total population in the study area.

A set questionnaire survey instrument written in the Malay language was distributed to record the data from the sampled farmers through face-to-face interviews. The questionnaire consists of questions regarding demographics data of the sampled farmers, the quantity of production inputs used in rockmelon cultivation, and yield of rockmelon per unit area.

The recorded quantity of production inputs and the yield of rockmelon per unit area were used in the computation and analysis of the energy use in rockmelon production. The amount of each energy input per hectare was multiplied with the energy equivalent of each input. The energy equivalent of inputs used in the calculation is shown in Table 1. Basic information about energy inputs and rockmelon yield were entered into computer spreadsheets. Energy use efficiency, energy productivity, specific energy and net energy gain were calculated by using the equations (1), (2), (3) and (4) as suggested by Demircan et al. (2006).

Energy use efficiency

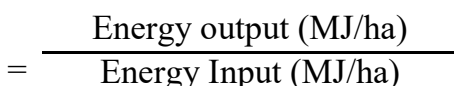

Energy productivity

$=\frac{\text { Rockmelon output }(\mathrm{kg} / \mathrm{ha})}{\text { Energy Input }(\mathrm{MJ} / \mathrm{ha})}$

Specific energy

Energy input (MJ/ha) Rockmelon output (kg/ha)

$$
\text { Net energy gain = } \begin{gathered}
\text { Energy output }(\mathrm{MJ} / \mathrm{ha}) \\
\text { Energy input }(\mathrm{MJ} / \mathrm{ha})
\end{gathered}
$$


The economic analysis of rockmelon production was analysed by calculating the gross value of production, the net return, and profit margin by using the equations (5), (6) and (7) as suggested by Mohammadi et al. (2008).

$$
\begin{aligned}
& =\text { Yield }(\mathrm{kg} / \mathrm{ha}) \times \text { Sale price } \\
& \text { (MYR/kg) }
\end{aligned}
$$

Gross value of production

Net return $($ MYR/ha $) \quad=($ MYR/ha $)-$ Total cost of production (MYR/ha)

\begin{tabular}{|c|c|c|c|}
\hline \multicolumn{4}{|c|}{ Energy } \\
\hline Components & Unit & $\begin{array}{l}\text { equivalent } \\
\text { (MJ/unit) }\end{array}$ & Reference \\
\hline \multicolumn{4}{|l|}{ Inputs } \\
\hline Human & $\mathrm{h}$ & 1.96 & Canakci et al. (2005) \\
\hline Machinery & $\mathrm{h}$ & 62.7 & Canakci et al. (2005) \\
\hline Diesel & $\mathrm{L}$ & 56.31 & Mohammadi et al. (2008) \\
\hline Fertilizers & $\mathrm{kg}$ & & \\
\hline Nitrogen $(\mathrm{N})$ & $\mathrm{kg}$ & 66.14 & Mohammadi et al. (2008) \\
\hline Phosphate $\left(\mathrm{P}_{2} \mathrm{O}_{5}\right)$ & $\mathrm{kg}$ & 12.44 & Mohammadi et al. (2008) \\
\hline Potassium $\left(\mathrm{K}_{2} \mathrm{O}\right)$ & $\mathrm{kg}$ & 11.15 & Mohammadi et al. (2008) \\
\hline Sulfur (S) & $\mathrm{kg}$ & 1.12 & Nagy (1999) \\
\hline Chemicals & $\mathrm{kg}$ & 120 & Mohammadi et al. (2008) \\
\hline Water & $\mathrm{m}^{3}$ & 1.02 & Mohammadi et al. (2008) \\
\hline Electricity & $\mathrm{kW}$ & 3.6 & Canakci et al. (2005) \\
\hline Seed & $\mathrm{kg}$ & 1.9 & Canakci et al. (2005) \\
\hline \multicolumn{4}{|l|}{ Output } \\
\hline Rockmelon & $\mathrm{kg}$ & 1.9 & Canakci et al. (2005) \\
\hline
\end{tabular}

Profit margin $(\%)=\frac{\text { Net return (MYR } / \text { ha) }}{\text { Gross value of production (MYR/ha) }} \times 100 \%$

Table 1. Energy equivalent of inputs and output in rockmelon production

\section{Results and discussion}

Table 2 shows the demographic profile of sampled rockmelon farmers. Ages of farmers were grouped based on Petry (2002), hence, the majority of the rockmelon farmers ages were middle-aged adults, followed by young adults, and older adults (older than 55 years old). Nevertheless, more intensive promotions were needed to encourage more young adults' generation to be involved in this cultivation.

On a gender basis, the majority of rockmelon farmers are male. This is normal in farms because the execution of agricultural tasks requires hard labour. Males are depicted to be more resilient for hard labour jobs as compared to females. Hence, male farmers are the primary source of manpower for this cultivation, while female farmers are secondary to assist male farmers in conducting everyday farm activity.
In terms of education, most of the rockmelon farmers come from the tertiary level of education. Some of them were government pensioners. Thus, from the data, it can be concluded that most of the farmers were educated people. With such high education level, the farmers were able to manage their farm correctly. In ) regard to land ownership, nearly all the farmers rented their lands for rockmelon farming. Rockmelon farmers mainly rented their farms by groups and were sponsored 6) by the Farmers' Organization Authority, which is a government agency under the Department of Agriculture 7) (DOA) of Malaysia. This program scheme was termed contract farming. It was believed that the program could

\begin{tabular}{|c|c|c|c|}
\hline & Variable & Frequency & Percentage $(\%)$ \\
\hline \multicolumn{4}{|l|}{ Age } \\
\hline & $18-35$ & 4 & 33.33 \\
\hline & $36-55$ & 5 & 41.67 \\
\hline & $>55$ & 3 & 25 \\
\hline & Total & 12 & 100 \\
\hline \multicolumn{4}{|c|}{ Gender } \\
\hline & Male & 11 & 91.67 \\
\hline & Female & 1 & 8.33 \\
\hline & Total & 12 & 100 \\
\hline \multicolumn{4}{|c|}{ Education Level } \\
\hline & Secondary & 2 & 16.67 \\
\hline & Tertiary & 10 & 83.33 \\
\hline & Total & 12 & 100 \\
\hline \multicolumn{4}{|c|}{ Farm Ownership } \\
\hline & Own & 8 & 66.67 \\
\hline & Rent & 4 & 33.33 \\
\hline & Total & 12 & 100 \\
\hline \multicolumn{4}{|c|}{ Experiences } \\
\hline & $1-3$ & 9 & 75 \\
\hline & $4-6$ & 1 & 8.33 \\
\hline & $7-9$ & 2 & 16.67 \\
\hline & Total & 12 & 100 \\
\hline
\end{tabular}
aid farmers in saving cost, time and energy as well as encouraging their business to be commercialized.

Table 2. Socio-demographics of respondent

\subsection{Breakdown energy of rockmelon cultivation}

Table 3 shows the breakdown of inputs used and the output obtained in rockmelon production in the study area. The results revealed that total input and output energy was $4475.62(\mathrm{MJ} / \mathrm{ha})$ and $23924.90(\mathrm{MJ} / \mathrm{ha})$, respectively. Distribution of the total energy inputs in rockmelon farms was also presented in Figure 1. Fertilizers consumed $73.29 \%$ of the total energy inputs, followed by electricity $10.65 \%$. Mainly electricity energy was consumed for operating pump in an irrigation system. Furthermore, chemicals (1.07\%) and human labour $(1.60 \%)$, while seed was the least demanding energy inputs for rockmelon cultivation at only $0.01 \%$ of the total sequestered energy. This is in agreement with Singh et al. (2004), who stated that the fertilizer took the 
Table 3. Total energy consumption in the rockmelon production

\begin{tabular}{lccccc}
\hline \multicolumn{1}{c}{ Energy } & Unit & Quantity input per & Total energy & Percentage of total & Rank \\
\hline Inputs & & & & & \\
$\quad$ Human Labor & $\mathrm{h}$ & 36.62 & 71.78 & 1.6 & 6 \\
$\quad$ Fertilizers & $\mathrm{kg}$ & & & & \\
$\quad$ Nitrogen $(\mathrm{N})$ & $\mathrm{kg}$ & 27.16 & 1796.36 & 40.14 & 1 \\
$\quad$ Phosphorus $\left(\mathrm{P}_{2} \mathrm{O}\right)$ & $\mathrm{kg}$ & 50.29 & 625.61 & 13.98 & 3 \\
$\quad$ Potassium $\left(\mathrm{K}_{2} \mathrm{O}_{2}\right)$ & $\mathrm{kg}$ & 75.66 & 843.61 & 18.85 & 2 \\
$\quad$ Sulphur $(\mathrm{S})$ & $\mathrm{kg}$ & 12.6 & 14.11 & 0.32 & 8 \\
Chemicals & $\mathrm{kg}$ & 0.4 & 48 & 1.07 & 7 \\
Electricity & $\mathrm{kW}$ & 132.4 & 476.64 & 10.65 & 5 \\
Water & $\mathrm{m}$ & 490.23 & 599.03 & 13.38 & 4 \\
$\quad$ Seed & $\mathrm{kg}$ & 0.25 & 0.48 & 0.01 & 9 \\
\hline Total energy inputs & & & 4475.62 & 100 & \\
\hline Output & $\mathrm{kg}$ & 12592.05 & 23924.9 & & \\
$\quad$ Rockmelon & &
\end{tabular}

largest amount of total energy in agriculture production in the developing countries.

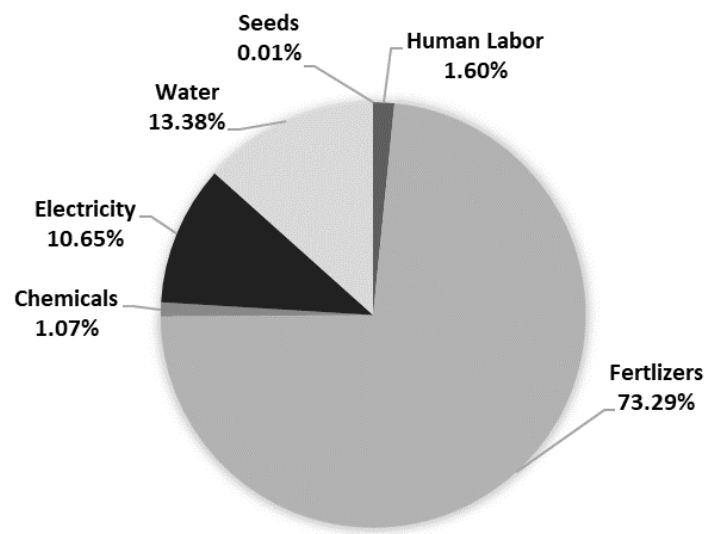

Figure 1. Share of energy inputs in rockmelon production

\subsection{Energy input-output ratio}

The energy use efficiency, specific energy, energy productivity and net energy of rockmelon production in Selangor were presented in Table 4. The energy efficiency coefficient from the ratio of output-inputs was 5.34. Thus, the value means the rockmelon production in the studied area saved 5.34 times of the amount of energy used for the production process. It can be considered as efficient use of farm inputs since the energy ratio is greater than one, then the production system is gaining energy, otherwise, if it is lesser than one it would mean it is losing energy. The energy output -inputs ratio of rockmelon production in the studied area was greater than the ratio of 4.08 in watermelon planted in the reduced irrigation system as studied by Moradi et al. (2015) and 2.19 in conventional rice production in Iran (Alipour et al., 2012). Apart from that, the ratio was also larger than 3.37 in apricot production in Turkey (Gezer et al., 2003) and 1.88, 1.14 and 0.95 in potato production in Iran (Mohammadi et al., 2008; Mortaza et al., 2010). As compared to others crop productions in Malaysia itself, the output-inputs ratio of rockmelon was also greater than $3.56,0.83$ and 0.62 of the inputs-output ratios of oil palm, pineapple and rubber, respectively (Azwan et al., 2016; Nazri and Pebrian, 2017; Zulekipli and Pebrian, 2019). However, the ratio was lower than 8.86 of energy use in rice cultivation, excluding irrigation input (Gevao et al., 2005).

Table 4. Energy inputs-output values

\begin{tabular}{lcc}
\hline Items & Unit & Total \\
\hline Energy inputs & $\mathrm{MJ} / \mathrm{ha}$ & 4475.62 \\
Energy output & $\mathrm{MJ} / \mathrm{ha}$ & 23924.9 \\
Yield & $\mathrm{kg} / \mathrm{ha}$ & 12592.05 \\
Energy use efficiency & $\mathrm{Unitless}$ & 5.34 \\
Specific energy & $\mathrm{MJ} / \mathrm{kg}$ & 0.36 \\
Energy productivity & $\mathrm{kg} / \mathrm{MJ}$ & 2.81 \\
Net energy & $\mathrm{MJ} / \mathrm{ha}$ & 11332.85 \\
\hline
\end{tabular}

\subsection{Energy forms in rockmelon production}

This study investigates energy forms in rockmelon production. The energy inputs in rockmelon production were formed from direct, indirect, renewable and nonrenewable energy as specified in Table 5. The direct energy was only $14.88 \%$ of total energy and much lower as compared to the indirect energy amounting to $85.12 \%$. A similar trend was seen in the ratios of renewable and non-renewable energy which shows that there are significant differences from each other. Renewable energy was only $15 \%$ and considered low. While the non -renewable energy share of $85 \%$ was still very high. Most of the renewable sources in rockmelon production are derived from fertilizer and chemicals. The nonrenewable energy sources will degrade and cannot be replaced.

\subsection{Economic analysis of rockmelon production}

The total cost of production in $\mathrm{kg}$ per hectare of rockmelon was expressed in Table 6. The price of rockmelon during the study period was calculated as MYR3.60/kg. With the yield of $12592.05 \mathrm{~kg} / \mathrm{ha}$, the 
Table 5. Distribution of energy forms

\begin{tabular}{ccc}
\hline Type of energy & $(\mathrm{MJ} / \mathrm{ha})$ & $\%$ \\
\hline Direct energy $^{\mathrm{a}}$ & 670.81 & 14.88 \\
Indirect energy $^{\mathrm{b}}$ & 3804.81 & 85.12 \\
Renewable energy $^{\mathrm{c}}$ & 671.29 & 15.00 \\
Non-renewable energy $^{\mathrm{d}}$ & 3804.33 & 85.00 \\
\hline
\end{tabular}

${ }^{a}$ human labour, water

${ }^{b}$ fertilizers, chemicals, seeds, electricity

'human labour, water, seeds

${ }^{\mathrm{d}}$ chemicals, fertilizers, electricity

computed gross value of production was MYR45331.38/ ha (Table 6). The total cost of production amounted MYR31756.80/ha. The net return amounted to MYR13574.58/ha was calculated by subtracting the gross value of production per hectare with the total cost of production per hectare. The profit margin of rockmelon farm was computed by dividing the net return with a gross value of production and it is expressed in per cent. Overall, the rockmelon farms in the studied area generated a profit margin of about $29.94 \%$. The calculated profit margin was considered high and good for business. This is in line with Corporate Finance Institute (2015), who stated that a good margin will vary considerably by industry, nonetheless, as a general rule of thumb, a $20 \%$ margin is considered high and good.

\section{Conclusion}

This study has successfully analysed energy use pattern and its economy on rockmelon production in Malaysian farms through a case study rockmelon farms in Klang, Selangor state of Malaysia. The rockmelon production consumed $4475.62 \mathrm{MJ} / \mathrm{ha}$ of energy. The largest amount of this energy was consumed by its fertilizing operation, where compounds $\mathrm{N}, \mathrm{P}, \mathrm{K}, \mathrm{S}$ fertilizers took about $73.29 \%$ from the total production energy, while the lowest amount of energy was seed $(0.01 \%)$. Based on the computed ratio of output-inputs of 5.34 , the rockmelon production was considered as highly effective in using energy in the crop production process. Other than that, the current production system gave the farmers $29.94 \%$ profit margin from their farms business. However, the direct energy use in rockmelon cultivation was lesser than indirect energy and portion of renewable energy was also smaller than non-renewable. Therefore, the involvement of modern techniques will be needed in order to optimize the farm capability in producing maximum renewable and direct energy from on-farm energy.

\section{Conflict of interest}

The authors declare no conflict of interest.
Table 6. Economic analysis in rockmelon production

\begin{tabular}{lc}
\hline \multicolumn{1}{c}{ Cost and return components } & Value \\
\hline Yield (kg/ha) & 12592.05 \\
Sale price (MYR/kg) & 3.60 \\
Gross value of production (MYR/ha) & 45331.38 \\
Cost of production (MYR/ha) & 31756.80 \\
Net return (MYR/ha) & 13574.58 \\
Profit margin (\%) & 29.94 \\
\hline
\end{tabular}

\section{Acknowledgements}

The authors are very grateful to the respondents in the study area for their excellence corporation for this research project.

\section{References}

Alipour, A., Veisi, H., Darijani, F., Mirbagheri, B. and Behbahani, A.G. (2012). Study and determination of energy consumption to produce conventional rice of the Guilan province. Research in Agricultural Engineering, 58(3), 99-106. https:// doi.org/10.17221/8/2011-RAE

Azwan, M.B., Norasikin, A., Abd Rahim, S., Norman, K. and Salmah, J. (2016). Analysis of energy utilisation in Malaysian oil palm mechanisation operation. Journal of Oil Palm Research, 28, 485-495. https:// doi.org/10.21894/jopr.2016.2804.10

Baker, L.B.B., Henning, J.C., Jenni, S. and Stewart, K.A. (2000). An economic and energy analysis of melon production using plasticulture. Acta Horticulturae, 519, 231-238. https://doi.org/10.17660/ ActaHortic.2000.519.24

Bórawski, P., Bełdycka-Bórawska, A., Szymańska, E.J., Jankowski, K.J., Dubis, B. and Dunn, J.W (2019). Development of renewable energy sources market and biofuels in The European Union. Journal of Cleaner Production, 228(10), 467-484. https:// doi.org/10.1016/j.jclepro.2019.04.242

Canakci, M., Akinci, I., Topakci, M. and Ozmerzi, A. (2005). Energy use pattern of some field crops and vegetable production: Case study for Antalya region, Turkey. Energy Conversion and Management, 46(4), 655-666.

https://doi.org/10.1016/ j.enconman.2004.04.008

Corporate Finance Institute. (2015). What is a profit margin? Retrieved on August 18, 2018 from https:// corporatefinanceinstitute.com/resources/knowledge/ accounting/profit-margin/

Demircan, V., Ekinci, K., Keener, H.M., Akbolat, D. and Ekinci, C. (2006). Energy and economic analysis of sweet cherry production in Turkey: A case study from Isparta province. Energy Conversion and 
Management, 47(13-14), 1761-1769. https:// doi.org/10.1016/j.enconman.2005.10.003

Duke, J.A. (1983). Handbook of Energy Crops. Retrieved on November 22, 2012 from http:// www.hort.purdue.edu/newcrop/duke_energy.

Elsoragaby, S., Yahya, A., Mahadi, R.M., Nawi, N.M. and Mairghany, M. (2019). Analysis of energy use and greenhouse gas emissions (GHG) of transplanting and broadcast seeding wetland rice cultivation. Energy, 189, 1-16. https:// doi.org/10.1016/j.energy.2019.116160

Gevao, B., Wan Ishak, S.M., Azmi, Y. and Chan, C.W. (2005). Analysis of energy consumption in lowland rice based cropping system of Malaysia. Journal of Science and Technology, 27(4), 819-826.

Gezer, I., Acaroglu, M. and Haciseferogullari, H. (2003). Use of energy and labor in apricot agriculture in Turkey. Biomass and Bio energy, 24, 215-219. https://doi.org/10.1016/S0961-9534(02)00116-2

Jankowski, K.J, Dubis, B., Sokólskia, M.M., Załuski, D., Bórawskia, P. and Szempliński, W. (2020). Productivity and energy balance of maize and sorghum grown for biogas in a large-area farm in Poland: An 11-year field experiment. Industrial Crops and Products, 148, 112326. https:// doi.org/10.1016/j.indcrop.2020.112326

Midilli, A., Dincer, I. and Ay, M. (2006). Green energy strategies for sustainable development. Energy Policy, 34(18), 3623-3633. https://doi.org/10.1016/ j.enpol.2005.08.003

Mohammadi, A., Tabatabaeefar, A., Shahin, S.H., Rafiee, S.H. and Keyhani, A., (2008). Energy use and economical analysis of potato production in Iran a case study: Ardabil province. Energy Conversion and Management, 49, 3566-3570. https:// doi.org/10.1016/j.enconman.2008.07.003

Moradi, R., Moghaddam, P.R. and Mansoor, H. (2015). Energy use and economical analysis of seedy watermelon production for different irrigation systems in Iran. Energy Reports, 1, 36-42. https:// doi.org/10.1016/j.egyr.2014.10.002

Morteza, Z., Omis, M., and Asadollah, A. (2010). Comparative study on energy use and cost analysis of potato production under different farming technologies in Hamadan province of Iran. Energy, 35, 2927-2933. https://doi.org/10.1016/ j.energy.2010.03.024

Muazu, A., Yahya, A., Ishak, W.I.W. and KhairunnizaBejo, S. (2015). Energy audit for sustainable wetland paddy cultivation in Malaysia. Energy, 87, 182-191. https://doi.org/10.1016/j.energy.2015.04.066

Nagy, C.N. (1999). Energy Coefficients for Agriculture
Inputs in Western Canada. Issue 2 of CSALE working paper series. Canada: Centre for Studies in Agriculture, Law and the Environment, University of Saskatchewan.

Nazri, M. and Pebrian, D.E. (2017). Analysis of energy consumption in pineapple cultivation in Malaysia: a case study. Pertanika Journal Science and Technology, 25(1), 17-28.

Petry N.M. (2002). A comparison of young, middleaged, and older adult treatment-seeking pathological gamblers. Gerontologist, 42(1), 92-9. https:// doi.org/10.1093/geront/42.1.92

Saidur, R., Ahamed, J.U., Masjuki, H.H., Mekhilef, S., Ali, M.B. and Furqon, M.H. (2011). An application of energy and exergy analysis in agricultural sector of Malaysia. Energy Policy, 39, 7922-7929. https:// doi.org/10.1016/j.enpol.2011.09.045

Singh, G., Singh, S. and Singh, J. (2004). Optimization of energy inputs for wheat crop in Punjab. Energy Conservation Management, 45, 453-465. https:// doi.org/10.1016/S0196-8904(03)00155-9

Statista. (2020). Yield of paddy in Malaysia 2012-2018. Retrieved on August 25, 2020 from Statista website: https://www.statista.com/statistics/795760/yield-ofpaddy-malaysia/.

Vescera, M. and Brown, R.N. (2016). Effects of three production systems on muskmelon yield and quality in New England. HortScience, 51(5), 510-517. https://doi.org/10.21273/HORTSCI.51.5.510

Zulekipli, H. A. and Pebrian D.E. (2019) Analysis of energy consumption in rubber cultivation in Malaysia: a case study. IOP Conference Series: Earth and Environmental Science, 327, 012004. https://doi.org/10.1088/1755-1315/327/1/012004 